Revue bibliographique pour le domaine irano-aryen

\title{
Bā šăerān-e emrūz. Tehrān, Arvīj, 1379/2000, 208 p. (Vol. 1). [Avec les poètes d'aujourd'hui, entretiens avec les poètes de la nouvelle génération]
}

\section{Christophe Balaÿ}

\section{(2) OpenEdition}

1 Journals

\section{Édition électronique}

URL : http://journals.openedition.org/abstractairanica/35893

DOI : 10.4000/abstractairanica.35893

ISSN : 1961-960X

Éditeur :

CNRS (UMR 7528 Mondes iraniens et indiens), Éditions de l'IFRI

\section{Édition imprimée}

Date de publication : 15 mai 2002

ISSN : 0240-8910

\section{Référence électronique}

Christophe Balaÿ, « Bā šāerān-e emrūz. Tehrān, Arvīj, 1379/2000, 208 p. (Vol. 1). [Avec les poètes d'aujourd'hui, entretiens avec les poètes de la nouvelle génération] », Abstracta Iranica [En ligne], Volume 23 | 2002, document 325, mis en ligne le 08 février 2010, consulté le 25 septembre 2020 URL : http://journals.openedition.org/abstractairanica/35893 ; DOI : https://doi.org/10.4000/ abstractairanica.35893

Ce document a été généré automatiquement le 25 septembre 2020.

Tous droits réservés 


\section{Bā šă erān-e emrūz. Tehrān, Arvīj, 1379/2000, 208 p. (Vol. 1). [Avec les poètes d'aujourd'hui, entretiens avec les poètes de la nouvelle génération]}

\section{Christophe Balaÿ}

L'A., lecteur assidu de la poésie persane contemporaine, fait un tour d'horizon de cette poésie avec huit des plus jeunes poètes de cette génération: Ḥāfez Mūsavī, 1954 ; Mehrdād Fallāḥ, 1960 ; Reḍā Čāyčīi, 1962 ; Hīvā Masīḥ, 1965 ; Kasrā Anqā’̄̄i 1967 ; Behzād Zarrīnpūr, 1968 ; Behzād Ḥājat, 1968 ; ‘Alī ‘Abdolreḍā’ī, 1969.

\section{INDEX}

Thèmes : 11.1.2. Littérature persane moderne

\section{AUTEURS}

CHRISTOPHE BALAŸ

IFRI - Téhéran 